\title{
UJI AKTIVITAS ANTIBAKTERI SENYAWA KATEKIN DARI DAUN TEH (Cameliasinensis L.var assamica) TERHADAP BAKTERI Micrococcusluteus
}

\author{
Elly Rustanti, Akyunul Jannah, A. Ghanaim Fasya \\ Jurusan Kimia, Fakultas Sains dan Teknologi UIN Maulana Malik Ibrahim Malang \\ Corresponding author : er_ellyrose@yahoo.com
}

\begin{abstract}
Zat antibakteri merupakan suatu zat yang dapat mengganggu pertumbuhan dan metabolisme bakteri, sehingga zat tersebut dapat menghambat pertumbuhanatau bahkan membunuh bakteri. Penelitian ini bertujuan untuk memanfaatkan bahan alam sebagai antibakteri alami. Penelitian ini ingin mengetahui bahwa daun teh (Camellia sinensis L. var assamica) yang efektif sebagai antibakteri alami dapat menghambat bakteri Micrococcus luteus. Penelitian ini meliputi ekstraksi yang dilakukan dengan metode maserasi menggunakansampel daun teh. Pemisahan ekstrak katekin dilakukan dengan KLT Analitik dengan variasi eluen yaitu etil asetat:air:asam format (18:1:1), toluena:aseton:asam format (3:3:1) dan kloroform:metanol:air $(6,5: 3,5: 1)$, untuk mencari eluen terbaik yang selanjutnya digunakan untuk KLT Preparatif. Selanjutnya hasil dari KLT Preparatif digunakan untuk uji antibakteri.Hasil penelitian menunjukkan bahwa hasil ekstrak katekin dari daun teh \pm 3,34 gram dari 50 gram sampel. Hasil KLT Analitik menunjukkan bahwa eluen terbaik untuk KLT Preparatif adalah etil asetat:air: asam format. Hasil uji antibakteri menunjukkan bahwa isolat 5 dari ekstrak daun teh memberikan efektivitas terbaik sebagai antibakteri Micrococcus luteus.
\end{abstract}

Kata Kunci: daun teh, katekin, antibakteri, Micrococcus luteus

\section{PENDAHULUAN}

Penambahan bahan pengawet pada makanan merupakan salah satu cara yang dapat digunakan untuk mencegah atau mengurangi kerusakan atau penurunan mutu bahan pangan. Bahan pengawet dapat mencegah kerusakan biologi yang disebabkan oleh mikroorganisme atau disebut dengan antibakteri.

Beberapa bahan pengawet atau komponen antibakteri telah digunakan sejak lama (Ardiansyah, 2007). Penggunaan pengawet sintetis pada berbagai makanan cukup meresahkan, contoh jenis bahan pengawet sintetis yang digunakan dalam industri makanan adalah formalin, boraks dan lain-lain.Fakta tersebut tentu saja sangat meresahkan masyarakat yang senantiasa ingin hidup sehat.Karena itu, upaya pencarian pengawet alami sangat perlu dilakukan (Anonymous, 2008).

Bahan pengawet dapat mencegah aktivitas bakteri dan perkembangbiakannya. Dengan kata lain, zat pengawet memiliki pengaruh langsung terhadap makanan yang diawetkan. Sebagian para ahli berpandangan bahwa zat ini tidak berbahaya selama tidak melebihi batas. Sementara yang lain, berpendapat bahwa hal itu tetap dianggap sebagai pemicu tumbuhnya kanker. Bahan-bahan pengawet seperti asam benzoat, dan garamnya yang paling berbahaya adalah sodium benzoat, asam metanol dan garamnya, asam sulfat dan garamnya. Sekalipun bahan-bahan ini dianggap racun bagi makhluk-makhluk kecil seperti bakteri, tetapi bisa dianggap juga sebagai racun bagi manusia, apabila dikonsumsi secara berlebihan (As-Sayyid, 2006).

Makanan yang diawetkan dengan bahan kimia seperti boraks dan formalin dalam berbagai bahan makanan yang beredar di pasaran seperti bakso, tahu serta bermacam produk ikan kering telah meresahkan masyarakat sejak beberapa waktu yang lalu hingga saat ini. Penambahan Bahan pengawet pada makanan tersebut dengan tujuan supaya produk lebih kenyal dan tahan lama (Anonymous, 2008).

Micrococcus termasuk bakteri gram positif, bersifat aerob, non patogen dan termasuk family micrococcaceae. Sel-sel 
Micrococcus berukuran 0.5 sampai $3.5 \mu \mathrm{m}$ dalam diameter, suhu optimum $25{ }^{0} \mathrm{C}$, menghasilkan pigmen, dan koloni dalam broth dan pada nutrient agar menghasilkan warna merah atau kuning. Micrococcus dapat menimbulkan noda-noda berwarna merah pada ikan. Kultur bakteri Micrococcus luteus berkembang sangat lambat dan tumbuh selama \pm 2 minggu (Robert, 1957).

Micrococcus luteus mampu mendegradasi senyawa-senyawa yang mengeluarkan cairan dalam menghasilkan bau yang tidak menyenangkan (bau busuk).Micrococcus luteus biasanya menyebabkan kebusukan pada produkproduk ikan (Thiagarajan, 2006).

Berkembangnya ilmu pengetahuan dan teknologi manusia harus lebih selektif dalam memilih makanan. Karena berdasarkan penelitian banyak makanan yang dicampuri dengan bahan kimia sehingga berakibat pada kesehatan manusia, salah satunya adalah penambahan antibakteri sintetik atau pengawetan secara kimia. Penggunaan antibakteri sintetik atau pengawet sintetik pada makanan seperti penambahan formalin sebagai pengawet makanan, jika dikonsumsi secara terus menerus akan menyebabkan penyakit. Adanya fenomena di atas mendorong manusia untuk mencari solusi yang terbaik dan tidak memberi mudhorot bagi kesehatan. Solusi yang dilakukan adalah gerakan back to nature atau kembali ke alam untuk mencari alternatif pengganti antibakteri sintetis. Salah satu sumber antibakteri alami adalah tanaman teh.

Indonesia merupakan negara dengan perkebunan teh yang cukup luas. Tanaman teh yang tumbuh di Indonesia sebagian besar merupakan varietas Assamica yang berasal dari India, berbeda dengan tanaman teh yang tumbuh di Jepang dan China yang merupakan teh varietas Sinensis. Teh varietas Assamica memiliki kelebihan dalam hal kandungan katekinnya (zat bioaktif utama dalam teh) yang lebih besar. Oleh karena itu, teh varietas Assamica ini sangat potensial untuk dikembangkan menjadi produk olahan pangan dan farmasi yang sangat bermanfaat bagi kesehatan (Hartoyo, 2003).

Selain sebagai obat, teh juga bisa digunakan sebagai bahan aditif berupa zat pengawet pada ikan, produk kosmetik dan makanan (Anonymous, 2008). Untuk memanfaatkan komponen bioaktif dalam teh dan memperluas aplikasinya diperlukan suatu bentuk produk yang mudah digunakan. Adapun bentuk teh yang praktis tersebut adalah ekstrak teh. Dalam ekstrak teh (kering atau konsentrat) terdapat kandungan komponen bioaktif katekin yang tinggi. Produk ekstrak teh ini dimanfaatkan untuk berbagai keperluan (pangan, kosmetik, dan lain-lain) atau diproses lebih lanjut untuk mendapatkan senyawa bioaktif murni (Hartoyo, 2003).

Allah menciptakan semua yang ada di dunia ini tidaklah sia-sia dari yang kecil hingga yang besar. Makhluk hidup (hewan, tumbuhan dan lain-lain) semuanya dapat dimanfaatkan oleh manusia jika manusia itu berfikir. Allah menjaga semua yang telah Ia ciptakan agar tetap hidup. Allah membuktikannya dengan diturunkan olehNya hujan sebagai sumber kehidupan, dan agar manusia dapat mensyukuri nikmat yang telah Allah berikan kepadanya. Allah telah menjelaskannya dalam surat $\mathrm{Al}$ An aam ayat 99 bahwa Allah telah menciptakan segala macam tanaman sebagai tanda-tanda kekuasaan Allah dan sebagai bahan untuk berfikir agar tercipta kemaslahatan umat.

Penjelasan di atas didukung dengan firman Allah dalam surat Asy-syu ara ayat 7 bahwa Allah menumbuhkan dari bermacam-macam tumbuhan yang baik yaitu subur dan bermanfaat. Seperti halnya teh yang di dalamnya banyak memberikan manfaat jika dikonsumsi oleh manusia sebagai minuman. Teh dalam kehidupan masyarakat secara umum dikenal sebagai minuman, selain itu juga dapat digunakan sebagai antibakteri alami atau pengawet alami.

Telah dilakukan penelitian tentang efisiensi polifenol daun teh melawan 
pemudaran warna oleh sinar UV pada ikan berwarna merah yaitu salmon.Karotenoid dalam sampel memudar warnanya seiring dengan matinya ikan.Namun, dengan penambahan polifenol teh, pemudaran warna merah daging ikan dapat dicegah lebih lama (Alamsyah, 2006).

Penelitian Amarowicz (2005) tentang pemisahan Epigallocatechin-3-gallate (EGCG) menggunakan KLT dengan fase diam plat silika gel dan 3 fase gerak yang digunakan untuk pemisahan EGCG dari ekstrak kasar daun teh dengan nilai Rf yang berbeda, yaitu etil asetat:air:asam format $(90: 5: 5 ; \mathrm{v} / \mathrm{v} / \mathrm{v})$ dengan nilai $\operatorname{Rf} 0,88$, toluena:aseton:asam format (30:30:10;v/v/v) dengan nilai Rf 0,61 dan kloroform:metanol:air $\quad(65: 35: 10 ; \mathrm{v} / \mathrm{v} / \mathrm{v})$ dengan nilai $\operatorname{Rf} 0,62$.

Berdasarkan uraian di atas, perlu dilakukan penelitian tentang uji aktivitas antibakteri senyawa katekin dari daun teh (Camelliasinensis, L. var. Assamica) yang efektif sebagai antibakteri alami dalam bentuk ekstrak antibakteri yang dapat menghambat pertumbuhan bakteriMicrococcusluteus. Penelitian ini merupakan salah satu upaya untuk mengoptimalkan pemanfaatan bahan alam hayati Indonesia, dengan tujuan untuk pencarian eluen terbaik dalam pemisahan senyawa aktif khususnya senyawa katekin sehingga diketahui fraksi-fraksi aktif yang mempunyai potensi sebagai antibakteri yang terdapat dalam hasil ekstrak daun teh.

\section{METODE PENELITIAN Alat dan bahan}

Alat yang digunakan dalam penelitianini adalah kertas saring, neraca analitik, seperangkat alat gelas, corong pisah, rotary evaporator, sentrifuge, seperangkat alat KLT, lampu UV, spektronik, cawan petri, tabung reaksi, kapas, kertas, jarum ose, incubator,pinset, autoklaf, bunsen, dan penggaris.

Bahan utama yang digunakan dalam penelitian ini adalah pucuk daun tehsegar yang diambil dari perkebunan teh Wonosari, Lawang, Malang. Bahan- bahankimia yang digunakan dalam penelitian ini, antara lain: plat silika gelGF254, akuades (H2O), kloroform (CHCl3) p.a, metanol $(\mathrm{CH} 3 \mathrm{OH})$ p.a, etil asetat(CH3COOC2H5) p.a, asam format (CH2O2) p.a, aseton (C3H6O) p.a, toluene (C6H5CH3) p.a, amoniak (NH3) dan larutan $\mathrm{FeCl} 3$.

Uji Antibakteri digunakan bahanbahan sebagai berikut: akuades steril,alkohol $90 \%$, kapas, kertas cakram, media Nutrient Agar (NA), Nutrient Borth(NB), pinisilin, streptomycin, biakan murni Micrococcus luteus.

\section{Preparasi sampel}

Daun teh dicuci terlebih dahulu, dipotong kecil-kecil, kemudian ditumbuk hingga halus, hasil yang diperoleh disebut sebagai sampel daun teh.

\section{Ekstraksi Senyawa Katekin dengan Metode Maserasi}

Sampel daun teh ditimbang 50 gram kemudian direndam dalam pelarut aquades sebanyak $200 \mathrm{~mL}$ dalam gelas beaker selama 2,5 jam sambil sesekali dikocok (Hukmah, 2007). Kemudian larutan ekstrak daun teh disaring dengan kertas saring.Filtrat ekstrak daun teh dimasukkan dalam corong pisah.

Ditambahkan kloroform sebanyak $100 \mathrm{ml}$ dalam corong pisah yang berisi fase air sambil dikocok-kocok, diulang 3 kali.Fase air yang diperoleh dimasukkan dalam corong pisah dan ditambahkan 100 $\mathrm{ml}$ etil asetat, di ulang 3 kali.Fase etil asetat yang diperoleh dipekatkan dengan rotary evaporator.Ekstrak pekat yang diperoleh digunakan untuk uji selanjutnya.

\section{Pemisahan Ekstrak Katekin dengan Kromatografi Lapis Tipis (KLT)}

\section{KLT Analitik}

Pada pemisahan dengan KLT analitik digunakan plat silika gel GF254 yang sudah diaktifkan dengan pemanasan dalam oven pada suhu 30-40 C selama 10 menit.Masing-masing plat dengan ukuran $2 \times 10 \mathrm{~cm} 2$. Ekstrak daun teh ditotolkan pada 
jarak $1 \mathrm{~cm}$ dari tepi bawah plat dengan pipa kapiler kemudian dikeringkan dan dielusi dengan fase gerak etil asetat:air:asam format $(18: 1: 1)$, toluen:aseton:asam format $(3: 3: 1)$, dan kloroform:metanol:air $(6,5: 3,5: 1)$ (Amarowicz, 2005). Setelah gerakan larutan pengembang sampai pada garis batas, elusi dihentikan. Noda-noda pada permukaan plat diuapkan dengan uap amoniak sambil diperiksa di bawah sinar UV pada panjang gelombang maksimum $254 \mathrm{~nm}$ warna biru pucat menunjukkan adanya katekin dan diuji kimia dengan menyemprotkan larutan $\mathrm{FeCl} 3$ warna hitam kebiruan menunjukkan adanya katekin (Robinson, 1995). Selanjutnya dengan memperhatikan bentuk noda pada berbagai larutan pengembang ditentukan perbandingan larutan pengembang yang paling baik untuk keperluan preparatif.

\section{KLT Preparatif}

Pada pemisahan dengan KLT preparatif digunakan plat silika gel GF254 dengan ukuran 5 x $20 \mathrm{~cm}$. Ekstrak pekat hasil ekstraksi ditotolkan sepanjang plat pada jarak $1 \mathrm{~cm}$ dari garis bawah dan $1 \mathrm{~cm}$ dari garis tepi. Selanjutnya dielusi dengan menggunakan eluen yang memberikan pemisahan terbaik pada KLT analitik. Noda-noda pada permukaan plat diuapkan dengan uap amoniak sambil diperiksa di bawah sinar UV pada panjang gelombang maksimum $254 \mathrm{~nm}$ warna biru pucat menunjukkan adanya katekin dan diuji kimia dengan menyemprotkan larutan $\mathrm{FeCl} 3$ warna hitam kebiruan menunjukkan adanya katekin (Robinson, 1995).

Noda yang diperoleh dikerok kemudian dilarutkan dalam pelarut air untuk uji antibakteri dan dilarutkan dalam pelarut metanol untuk identifikasi dengan spektrofotometer FTIR, kemudian disentrifuge untuk mengendapkan silikanya.Berat isolat diketahui dengan cara menghitung selisih antara berat silika gelsebelum dengan sesudah sentrifuge (Day dan Underwood, 1986 dalam Sulami2004), kemudian isolat siap digunakan untuk analisa berikutnya.

\section{Uji Antibakteri}

\section{Sterilisasi Alat dan Bahan}

Sterilisasi alat dan bahan dengan cara menutup alat-alat yang akandisterilkan dengan alumunium foil atau kapas, kemudian dimasukkan ke dalamautoklaf pada suhu 121 0C dengan tekanan 15 psi (per square inchi) selama 15menit.

\section{Pembuatan Media}

Media yang disiapkan adalah media padat agar miring untuk peremajaanbiakan murni dan uji antibakteri senyawa katekin dari ekstrak daun teh padabakteri Micrococcus luteus. Pembuatan media dilakukan dengan cara sebanyak 2 gram nutrien agar dilarutkan dalam 100 mLakuades dalam gelas beaker. Kemudian dimasukkan dalam erlenmeyer danditutup dengan kapas dan kertas. Suspensi dipanaskan hingga mendidih dan dimasukkan ke dalam 7 tabung reaksi (masing-masing $10 \mathrm{~mL}$ untuk 5 tabung reaksi dan $5 \mathrm{~mL}$ untuk 2 tabung reaksi) dan ditutup dengan kapas. Tabung tabungtersebut kemudian disterilkan dalam autoklaf suhu $121 \quad$ OC selama 15 menit,kemudian diletakkan dalam posisi miring selama 24 jam pada suhu kamar.

\section{Peremajaan Biakan MurniM. luteus.}

Biakan murni Micrococcus luteus diremajakan pada media padat agar miring dengan cara menggoreskan jarum oseyang mengandung bakteri tersebut secara aseptik dan tabung media ditutupdengan kapas. Selanjutnya biakan Micrococcusluteus diinkubasi pada suhu 25 0C dalam inkubator.

\section{Pembuatan Kurva Pertumbuhan bakteri dengan Media NB}

Satu tabung subkultur masing-masing bakteri hasil peremajaan ditanamdalam 100 $\mathrm{mL}$ media pertumbuhan $\mathrm{NB}$, kemudian Micrococcus luteus diinkubasi pada suhu $250 \mathrm{C}$, setiap selang waktu 2 jamdiambil 1 $\mathrm{mL}$ dan diencerkan sampai volume $10 \mathrm{~mL}$ sampai tumbuh optimum, kemudian dilakukan pengukuran densitas optik 
pertumbuhan sel masing-masing bakteri pada panjang gelombang $620 \mathrm{~nm}$ menggunakan spektronik. Setelah itudibuat grafik hubungan waktu inkubasi dengan densitas optik dan diperoleh kurva pertumbuhan bakteri Micrococcus luteus.

\section{Pembuatan Larutan BakteriM. Luteus}

Diambil 1 ose dari hasil peremajaan biakan murniMicrococcus luteus dilarutkan dalam 10 mLakuades steril.

\section{Uji Efektivitas Antibakteri}

Media agar berisi $10 \mathrm{~mL}$ nutrien agar (tahap 2) dipanaskan hingga mencair dan kemudian di dinginkan sampai suhu \pm 40 0C. Larutan nutrien agardituang dalam cawan petri dan dicampur dengan $0,1 \mathrm{~mL}$ larutan bakteri Micrococcus luteus, kemudian dihomogenkan dan dibiarkan hingga memadat. Kertas cakram (diameter $5 \mathrm{~mm}$ ) diresapkan dalam isolat dan kontrol. Proses peresapan dilakukan dengan caramerendam isolat-isolat hasil KLTP dengan variasi sampel dan kontrol. Kontrol positif untuk bakteri $M$. luteus menggunakan pinisilin $25 \mathrm{mg} / \mathrm{mL}$, dan pelarut Aquades (sebagai kontrol negatif). Kertas cakram tersebut kemudian diletakkan di atas permukaan media bakteri menggunakan pinset danditekan sedikit, kemudian diinkubasi pada suhu 25 oC selama masa pertumbuhan optimum masing-masing bakteri, kemudian diukur diameter zona hambatnya. Diameter zona hambatan yang terbentuk diukur menggunakan penggaris untuk menentukan efektivitas antibakteri. Pengukuran zona hambatan dilakukan dengan mengukur diameter daerah jernih. Diameter zona hambat adalah diameter yang tidak ditumbuhi bakteri di sekitar kertas cakram dikurangi diameter kertascakram.

\section{HASIL DAN PEMBAHASAN Preparasi Sampel}

Sampel yang digunakan dalam penelitian ini adalah daun teh yang segar. Perlakuan daun teh yang segar dilakukan dengan menimbang sebanyak 80 gram daun teh segar dan dicuci dengan air bersih. Daun yang sudah bersih kemudian dihaluskan dengan menggunakan mortar, perlakuan ini bertujuan untuk memperluas permukaan sehingga mudah dalam pengekstraksian. Hasil yang diperoleh disebut sebagai sampel daun teh berwarna hijau.

\section{Ekstraksi Senyawa Katekin}

Pada tahap ini dilakukan ekstraksi daun teh dengan tujuan mendapatkan ekstrak kasar senyawa katekin dari daun teh. Proses ekstraksi merupakan penarikan komponen aktif menggunakan pelarut tertentu. Komponen aktif yang diambil adalah senyawa katekin dari daun teh menggunakan metode maserasi. Pemilihan metode maserasi pada penelitian ini dikarenakan senyawa katekin rentan terhadap panas sehingga tidak bagus menggunakan metode soxhlet. Hal ini didukung oleh penelitiannya Cheong, et.al (2005) dalam Hukmah (2007) bahwa dengan menggunakan metode soxhlet konsentrasi senyawa katekin mengalami penurunan dibandingkan dengan metode maserasi.

Pelarut yang digunakan untuk ekstraksi adalah pelarut aquades. Aquades sering digunakan untuk mengekstrak senyawa katekin karena senyawa katekin merupakan senyawa yang mengandung 2 cincin aromatik dengan gugus hidroksil lebih dari satu. Robinson (2005) menyatakan semakin banyak gugus hidroksil suatu senyawa fenol memiliki tingkat kelarutan dalam air semakin besar atau bersifat polar sehingga dipilih pelarut polar.

Sampel daun teh ditimbang50 gram kemudian direndam dalam $200 \mathrm{~mL}$ pelarut selama 2,5 jam. Proses ekstraksi akan berlangsung optimal dengan tersedianya waktu kontak yang cukup antara pelarut dan sampel. Selama proses perendaman dilakukan beberapa kali pengocokan untuk menyempurnakan kontak antara pelarut dan sampel. Larutan kemudian disaring dan diperoleh filtrat dari pelarut dengan warna 
hijau pada ekstrak daun teh ditentukan oleh adanya klorofil.

Filtrat hasil penyaringan kemudian difraksinasi dengan cara ekstraksi menggunakan corong pisah, filtrat ditambahkan kloroform untuk mengambil senyawa-senyawa yang bersifat nonpolar, diantaranya lemak, klorofil, kafein dan lainlain. Penambahan kloroform diulang untuk memaksimalkan proses pengambilan senyawa yang bersifat non polar.

Penambahan kloroform menyebabkan terbentuknya dua fase yaitu fase air dan fase kloroform. Fase kloroform ditampung dan fase air diambil untuk dilakukan tahap fraksinasi selanjutnya menggunakan etil asetat. Penambahan etil asetat berfungsi untuk mengambil senyawa katekin. Penambahan etil asetat diulang untuk memaksimalkan pengambilan senyawa katekin. Langkah selanjutnya fase air ditampung dan diambil fase etil asetat dari sampel daun teh dengan warna fase kuning pekat dan berat sampel 3,34 gram.

Ekstrak pekat yang dihasilkan memilikiwarna kuning pekatmenunjukkan bahwa klorofil yang terdapat dalam ekstrak daun teh sudah tidak tampak karena terikat oleh kloroform, dan ketika ditambahkan etil asetat warna hijau menjadi kuning pekat.

Fase etil asetat kemudian dipekatkan dengan rotary evaporator sehingga diperoleh ekstrak pekat. Proses evaporasi ini dilakukan untuk menghilangkan pelarutnya. Pelarut yang diuapkan (etil asetat) memiliki titik didih antara $77{ }^{\circ} \mathrm{C}$, sehingga proses evaporasi berlangsung cepat. Ekstrak pekat tersebut kemudian dipisahkan dengan Kromatografi Lapis Tipis.

\section{Pemisahan Ekstrak Katekin dengan Kromatografi Lapis Tipis (KLT) \\ 1. KLT Analitik}

Pendugaan secara kualitatif senyawa katekin daun teh dari masing-masing sampel dilakukan dengan metode Kromatografi Lapis Tipis (KLT). KLT merupakan metode pemisahan senyawa kimia dengan menggunakan fase diam dan fase gerak. Pemisahan katekin dari ekstrak kasar dilakukan menggunakan plat silika gel dengan eluen etil asetat:air:asam format $(18: 1: 1)$, toluen:aseton:asam format $(3: 3: 1)$, dan kloroform:metanol:air (6,5:3,5:1). Penggunaan berbagai macam eluen pada pemisahan ini untuk mencari eluen terbaik dan dapat memisahkan senyawa katekin yang terkandung dalam daun teh.

Hasil elusi dari kedua ekstrak ini dengan variasi bentuk sampel dapat ditunjukkan pada Gambar 1. dan Tabel 1.

Tabel 1. Nilai Rf Pada Kromatogram Hasil KLT Analitik dengan Variasi Eluen

\begin{tabular}{|c|c|c|}
\hline \multicolumn{3}{|c|}{ Nilai Rf dari ekstrak daun teh } \\
$\begin{array}{c}\text { Etil } \\
\text { asetat:air:asa } \\
\mathrm{m} \text { format } \\
(18: 1: 1)\end{array}$ & $\begin{array}{c}\text { Toluena:ase } \\
\text { ton:asam } \\
\text { format } \\
(3: 3: 1)\end{array}$ & $\begin{array}{c}\text { Kloroform: } \\
\text { metanol: } \\
\text { air } \\
(6,5: 3,5: 1)\end{array}$ \\
\hline $\begin{array}{c}\text { 1. } \mathrm{Rf}=0,22 \\
\text { 2. } \mathrm{Rf}=0,47\end{array}$ & $\begin{array}{l}\text { 1. } \mathrm{Rf}=0,39 \\
\text { 3. } \mathrm{Rf}=0,64\end{array}$ & \\
2. $\mathrm{Rf}=0,61$ & 1. Rf $=0,90$ \\
5. $\mathrm{Rf}=0,86$ & 3. $\mathrm{Rf}=0,74$ & \\
6. $\mathrm{Rf}=0,95$ & & \\
\hline
\end{tabular}

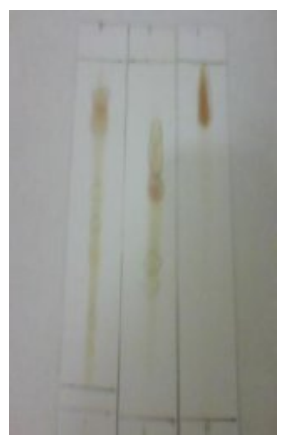

(1) (2) (3)

Ekstrak daun teh

Keterangan: Eluen: (1) etil asetat: air: asam format (2) toluen: aseton: asam format $(3: 3: 1)$ dan (3) kloroform: metanol: air $(6,5: 3,5: 1)$

\section{Gambar 1. Hasil KLT Analitik}

Pada Gambar 2. dan Tabel 3. dapat dilihat bahwa perbedaan jumlah noda pada masing-masing eluen tergantung pada sifat 
kepolaran noda, fase diam dan fase geraknya. Pemisahan ini didasarkan pada sifat polaritas senyawa. Senyawa yang memiliki polaritas hampir sama dengan fase geraknya akan terelusi terlebih dulu dibandingkan senyawa dengan sifat polaritas yang berbeda dengan fase geraknya. Hal ini yang mengakibatkan nilai Rf dari masing-masing noda berbeda karena jarak tempuh antara senyawa dan fase geraknya tergantung pada sifat polaritasnya.

Hasil pemisahan dari kedua ekstrak menunjukkan bahwa eluen etil asetat: air: asam format (18:1:1) mampu memisahkan ekstrak pekat dengan baik karena menghasilkan noda yang paling banyak dengan pemisahan yang jelas yaitu ekstrak daun teh menghasilkan 6 noda, munculnya 6 noda ini tergantung pada kelarutan senyawa dalam pelarut yaitu interaksi antara molekul-molekul senyawa dengan pelarut dan melekatnya senyawa pada fase diam yaitu interaksi antara senyawa dengan silika gel. Kedua hal tersebut akan mempengaruhi mudahnya senyawa ditarik oleh fase gerak (pelarut) keluar dari permukaan fase diam (silika gel) sehingga muncul 6 noda karena kepolaran senyawasenyawa yang dipisahkan mempunyai tingkatan yang sama dengan fase diam dan fase geraknya.

Eluen dengan campuran toluen:aseton:asam format (3:3:1) dalam pemisahan cukup bagus yaitu ekstrak daun teh menghasilkan 3 noda, munculnya 3 noda ini karena senyawa-senyawa yang dipisahkan kurang berinteraksi dengan fase gerak (pelarut) karena kepolaran senyawanya hampir sama dengan fase diam sehingga yang dapat larut dalam pelarut hanya sebagian senyawa yang kepolarannya sama.

Sedangkan eluen dengan campuran kloroform:metanol:air $\quad(6,5: 3,5: 1)$ dalam pemisahan kurang bagus yaitu ekstrak daun teh menghasilkan 1 noda, munculnya 1 noda ini karena senyawa-senyawa yang dipisahkan kurang berinteraksi dengan fase gerak (pelarut) karena kepolaran senyawanya hampir sama dengan fase diam sehingga yang dapat larut dalam pelarut hanya sebagian senyawa yang kepolarannya sama dan senyawa tidak terpisahkan dengan baik sehingga perlu adanya perubahan eluen.

Eluen yang dapat memisahkan senyawa katekin yang baik adalah etil asetat:air:asam format (18:1:1), kemudian toluen:aseton:asam format $(3: 3: 1)$, dan kloroform:metanol:air $(6,5: 3,5: 1)$. Hal ini dikarenakan eluen etil asetat:air:asam format (18:1:1) bersifat agak polar dan kepolarannya hampir sama dengan ekstrak katekin yang dipisahkan sehingga noda yang diperoleh lebih banyak. Menurut Robinson (2005), etil asetat merupakan pelarut yang baik untuk menangani katekin.

Fase diam juga mempengaruhi pemisahan katekin, fase diam yang digunakan adalah silika gel. Silika gel adalah bentuk dari silikon dioksida (silika). Atom silikon dihubungkan oleh atom oksigen dalam struktur kovalen yang besar. Namun, pada permukaan silika gel, atom silikon berlekatan pada gugus -OH. Jadi, pada permukaan silika gel terdapat ikatan $\mathrm{Si}-\mathrm{O}-\mathrm{H}$ selain $\mathrm{Si}-\mathrm{O}-\mathrm{Si}$. Permukaan silika gel sangat polar dan karenanya gugus $-\mathrm{OH}$ dapat membentuk ikatan hidrogen dengan senyawa-senyawa yang sesuai disekitarnya.

Hasil KLT kemudian dilakukan uji identifikasi senyawa katekin dengan pereaksi $\mathrm{FeCl}_{3}$, pereaksi ini telah digunakan secara luas untuk mengidentifikasi senyawa fenol terutama katekin akan menghasilkan warna hitam kebiruan (Robinson, 2005). Plat yang telah disemprot dengan pereaksi $\mathrm{FeCl}_{3}$ diangin-anginkan sampai kering kemudian diidentifikasi plat tersebut dibawah sinar lampu UV pada panjang gelombang $254 \mathrm{~nm}$ (untuk memperjelas spot yang terbentuk).

Hasil identifikasi KLT ditunjukkan pada gambar di bawah ini: 


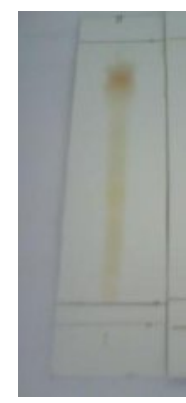

(a)

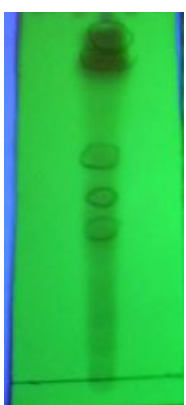

(b)

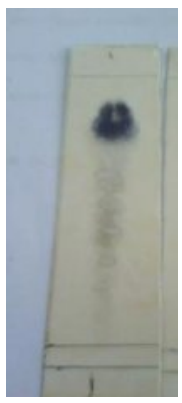

(c)
Keterangan: Hasil Identifikasi KLT dengan (a) tanpa lampu UV, (b) lampu UV + amoniak, dan (c) larutan $\mathrm{FeCl}_{3}$.

Gambar 2. Hasil Identifikasi KLT dengan eluen etil asetat:air:asam format (18:1:1)

Berdasarkan hasil dari KLT analitik maka eluen etil asetat:air:asam format (18:1:1) memberikan elusi terbaik, karena pemisahan didasarkan pada sifat polaritas senyawa. Senyawa katekin memiliki polaritas yang hampir sama dengan eluen etil asetat:air:asam format (18:1:1) sehingga kemampuan dalam memisahkan senyawa tersebut lebih baik. Dan eluen tersebut kemudian digunakan dalam pemisahan senyawa katekin dengan KLT preparatif.

\section{KLT Preparatif}

Hasil pemisahan kromatografi lapis tipis preparatif hampir sama dengan KLT kualitatif hanya berbeda pada kuantitas dari ekstrak yang digunakan. Dimana pada KLT prepararif digunakan plat KLT silika gel dengan ukuran yang lebih besar yaitu dengan ketebalan $\pm 1 \mathrm{~mm}$. Pada KLTP digunakan eluen terbaik KLTA yaitu etil asetat:air:asam format (18:1:1), karena mampu memisahkan ekstrak pekat dengan baik yaitu ekstrak daun teh menghasilkan 6 noda, dan antara noda satu dengan yang lainnya terpisah jelas. Hasil noda pada KLTP ditunjukkan pada gambar berikut:

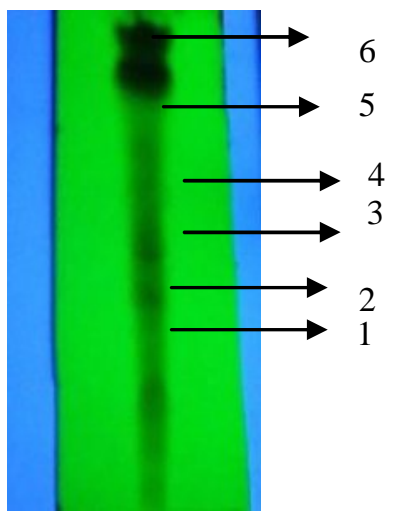

Gambar 3. Noda hasil KLTP

Pada Gambar 3. Sampel ekstrak daun teh menghasilkan 6 noda dengan nilai $\mathrm{Rf}$ sebagai berikut:

Tabel 2. Nilai Rf dan Warna Noda pada Kromatogram Hasil KLT Preparatif Ekstrak daun teh

\begin{tabular}{|c|c|c|c|c|}
\hline \multirow{2}{*}{ Noda } & \multirow{2}{*}{ Rf } & \multicolumn{3}{|c|}{ Wanpa } \\
UV & $\begin{array}{c}\text { Amoniak } \\
\text { UV }\end{array}$ & $\mathrm{FeCl}_{3}$ \\
\hline 1 & 0,22 & Kuning & $\begin{array}{c}\text { Biru } \\
\text { pucat }\end{array}$ & $\begin{array}{c}\text { Hitam } \\
\text { biru }\end{array}$ \\
\hline 2 & 0,47 & Kuning & $\begin{array}{c}\text { Biru } \\
\text { pucat }\end{array}$ & $\begin{array}{c}\text { Hitam } \\
\text { biru }\end{array}$ \\
\hline 3 & 0,64 & Kuning & $\begin{array}{c}\text { Biru } \\
\text { pucat } \\
\text { Biru } \\
\text { pucat }\end{array}$ & $\begin{array}{c}\text { Hitam } \\
\text { biru } \\
\text { biru }\end{array}$ \\
\hline 4 & 0,78 & Ungu & $\begin{array}{c}\text { Biru } \\
\text { pucat }\end{array}$ & $\begin{array}{c}\text { Hitam } \\
\text { biru }\end{array}$ \\
\hline 5 & 0,86 & Ungu & $\begin{array}{c}\text { Biru } \\
\text { pucat }\end{array}$ & $\begin{array}{c}\text { Hitam } \\
\text { biru }\end{array}$ \\
\hline 6 & 0,95 & Orange \\
\hline
\end{tabular}

Warna biru pucat ketika diuapi amoniak dan disinari lampu UV dari ke-6 noda tersebut merupakan senyawa katekin, namun karena data kromatogram tidak menyertakan senyawa standart, maka belum dapat ditentukan jenis komponen senyawa yang terekstrak. Menurut Robinson (1995) senyawa katekin ketika diuapi dengan uap amoniak sambil diperiksa dibawah sinar ultraviolet (UV) berfluoresensi biru pucat.

Pada lampu UV $254 \mathrm{~nm}$, plat akan berflouresensi dan penampakan noda terjadi 
karena adanya daya interaksi antara sinar UV dengan indikator fluoresensi yang terdapat pada Plat. Fluoresensi cahaya yang tampak merupakan emisi cahaya yang dipancarkan oleh komponen tersebut ketika elektron yang tereksitasi dari tingkat energi dasar ke tingkat energi yang lebih tinggi kemudian kembali ke keadaan semula sambil melepaskan energi.

Penyemprotan dengan larutan $\mathrm{FeCl}_{3}$ menunjukkan warna hitam kebiruan dan diduga merupakan senyawa katekin. Menurut Robinson (1995) suatu senyawa yang direaksikan dengan $\mathrm{FeCl}_{3}$ jika terjadi warna hitam kebiruan, merupakan bukti adanya 3,4,5-trihidroksi fenol (seperti galokatekin).Noda yang dihasilkan pada KLT preparatif kemudian dikerok dan dilarutkan dalam air untuk uji antibakteri.

\section{Uji Antibakteri}

\section{Penyiapan media dan peremajaan biakan murni $M$. luteus}

Media pertumbuhan mengandung nutrisi dan zat-zat yang diperlukan oleh bakteri untuk tumbuh. Media cair digunakan untuk produksi atau pembuatan kurva pertumbuhan, sedangkan media padat digunakan untuk peremajaan biakan murni bakteri. Peremajaan dilakukan untuk menjaga ketersediaan nutrisi, regenerasi bakteri dan menghindari terjadinya perubahan karakter dari biakan murni bakteri.

\section{Pembuatan kurva pertumbuhan bakteri dengan media Nutrient Borth}

Kurva pertumbuhan menggambarkan fase-fase yang ada dalam siklus hidup Micrococcusluteus yang meliputi fase adaptasi, fase logaritmik, fase stasioner, dan fase kematian. Berdasarkan kurva pertumbuhan dapat ditentukan waktu panen yang ideal adalah pada saat pertumbuhan bakteri mendekati fase stasioner. Pada saat ini, jumlah sel bakteri mendekati maksimum seiring dengan kematian bakteri.

Pembuatan kurva pertumbuhan diawali dengan penumbuhan biakan murni bakteri yang telah diremajakan pada medium cair dan diinkubasi pada inkubator dengan suhu $25{ }^{0} \mathrm{C}$ sambil digoyanggoyang. Hal ini dilakukan untuk mengatur aerasi dan agitasi yang menjaga kondisi fisika dan kimia media pertumbuhan serta memperlancar transfer nutrisi ke dalam sel.

Pertumbuhan bakteri diamati dengan mengukur densitas optik (DO) media pertumbuhan pada panjang gelombang 620 nm setiap selang waktu 2 jam sampai nilai DO media konstan dan akhirnya mengalami penurunan. Nilai DO sebanding dengan massa sel yang terdapat dalam media, makin banyak massa sel makin besar DOnya. Kemudian kurva pertumbuhan dibuat dengan membuat grafik hubungan waktu inkubasi dengan nilai DO media. Pada penelitian ini kurva pertumbuhan bakteri Micrococcus luteus pada penelitian ini adalah sebagai berikut:

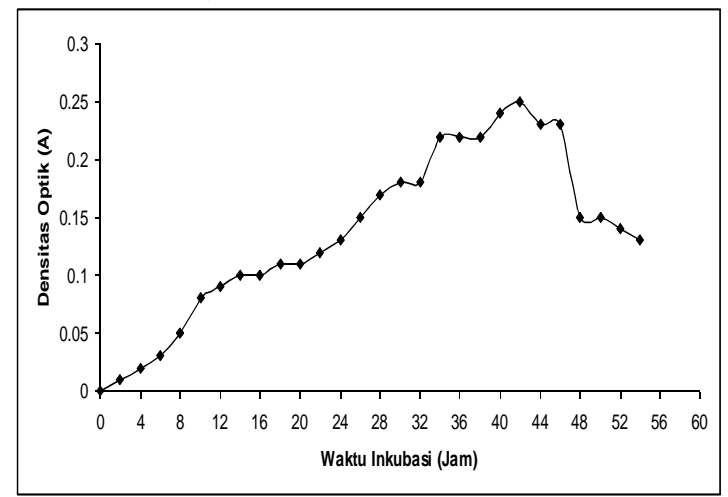

Gambar 4. Kurva Pertumbuhan M. Luteus

Dari Gambar 4. diketahui bahwa pertumbuhan Micrococcusluteus melewati beberapa fase, yaitu: fase adaptasi yang terjadi pada waktu inkubasi 0-6 jam, pada fase ini pertumbuhan Micrococcusluteus sangat lamban karena masih beradaptasi dengan media. Fase logaritmik pada waktu inkubasi 6-34 jam, pada fase ini Micrococcusluteus mengalami pembelahan sel secara terus menerus yang ditandai meningkatnya jumlah sel sampai mencapai jumlah maksimum. Fase stasioner dicapai waktu inkubasi 34 jam, pada fase ini pembelahan sel Micrococcus luteus sebanding dengan jumlah kematian sehingga tidak terjadi peningkatan jumlah sel. Fase kematian terjadi setelah diinkubasi 
selama 46 jam, pada fase ini terjadi penurunan jumlah sel Micrococcusluteus karena kematian sel akibat habisnya nutrisi penting dalam media. Oleh karena itu, dalam penelitian ini pembuatan inokulum dilakukan selama waktu inkubasi 14 jam yang merupakan tengah-tengah fase logaritmik dan zona hambat bakteri Micrococcusluteus dapat diukur setelah diinkubasi selama 34 jam.

\section{Uji Aktivitas \\ Micrococcucluteus}

Antibateri

Micrococcusluteus merupakan bakteri gram positif. Uji aktivitas senyawa katekin sebagai antibakteri Micrococcusluteus dilakukan dengan mengukur zona hambatan yang terbentuk disekitar cakram. Perlakuan pada kontrol positif untuk bakteri Micrococcusluteus menggunakan pinisilin $25 \mathrm{mg} / \mathrm{ml}$ dan kontrol negatif air menunjukkan bahwa pelarut air tidak mampu membunuh bakteri, hal ini ditunjukkan dengan pertumbuhan bakteri yang terus melewati cakram tanpa terhambat pertumbuhannya. Hasil uji aktivitas 6 isolat hasil KLTP dengan konsentrasi $15 \mathrm{mg} / \mathrm{ml}$ dan tiga kali ulangan terhadap bakteri Micrococcusluteus adalah sebagai berikut:

Tabel 3. Data zona hambat senyawa katekin ekstrak daun teh hasil KLT sebagai antibakteri M. Luteus

\begin{tabular}{|c|c|c|c|c|c|}
\hline \multirow[t]{2}{*}{ No. } & \multirow[t]{2}{*}{ Cakram } & \multicolumn{3}{|c|}{$\begin{array}{l}\text { Diameter zona } \\
\text { hambat }(\mathrm{mm})\end{array}$} & \multirow{2}{*}{$\begin{array}{l}\text { Rata- } \\
\text { rata } \\
(\mathrm{mm})\end{array}$} \\
\hline & & 1 & 2 & 3 & \\
\hline 1. & Isolat 1 & 13,0 & 12,0 & 10,0 & 11,7 \\
\hline 2. & Isolat 2 & 14,0 & 13,0 & 15,0 & 14,0 \\
\hline 3. & Isolat 3 & 20,0 & 20,0 & 18,0 & 19,3 \\
\hline 4. & Isolat 4 & 10,0 & 10,0 & 8,00 & 9,30 \\
\hline 5. & Isolat 5 & 22,0 & 21,0 & 21,0 & 21,3 \\
\hline 6. & Isolat 6 & 15,0 & 13,0 & 15,0 & 14,3 \\
\hline 7. & $\begin{array}{c}\text { Kontrol } \\
+\end{array}$ & 40,0 & 37,5 & 35,0 & 37,5 \\
\hline 8. & Kontrol - & 0,00 & 0,00 & 0,00 & 0,00 \\
\hline
\end{tabular}

Tabel 3., menunjukkan adanya perbedaan dari beberapa isolat terhadap zona hambatan bakteri Micrococcusluteus. Pada isolat 1, 2 dan 6 aktivitas antibakteri mulai tampak namun respon hambatan pertumbuhannya masih lemah, dan pada isolat 3 aktivitas antibakteri juga menunjukkan respon hambatan pertumbuhan yang kurang kuat atau sedang dengan zona hambat sebesar 19,3 mm, pada isolat 4 aktivitas antibakteri menunjukkan tidak adanya respon hambatan pertumbuhan. Sedangkan, pada isolat 5 dengan zona hambatan $21,3 \mathrm{~mm}$ yang mana respon hambatan pertumbuhannya kuat.

Dari Tabel 3. diketahui bahwa isolat yang efektif sebagai antibakteri Micrococcus luteus adalah isolat 5. Isolat 5 dari ekstrak daun teh mempunyai efektivitas antibakteri yang paling kuat yaitu dengan memberikan zona hambat 21,3 $\mathrm{mm}$ yang ditunjukan pada gambar berikut:

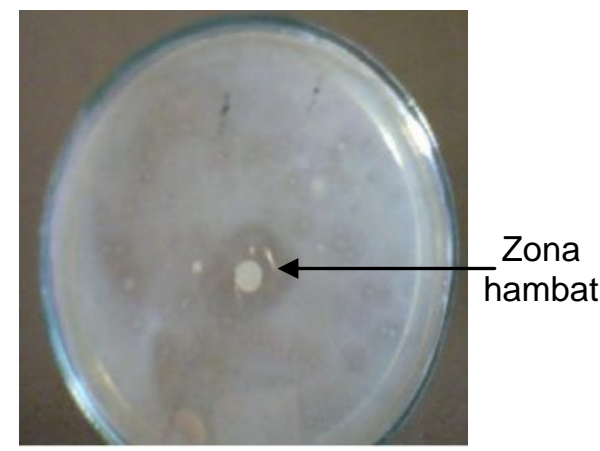

Gambar 5. Isolat 5 (21,3 mm)

\section{Mekanisme Kerja Senyawa Katekin Terhadap Pertumbuhan Bakteri}

Aktivitas antibakteri terbaik yang menghambat Micrococcusluteus adalah isolat 5 dari ekstrak daun teh dengan zona hambat 21,3 mm. Micrococcusluteus adalah bakteri gram positif yang susunan komponen dinding selnya lebih sederhana. Bakteri gram positif $90 \%$ kandungan dinding selnya adalah peptidoglikan, selebihnya adalah asam teikoat (Fardiaz, 1986 dalam Ardiansyah, 2007).

Senyawa katekin termasuk senyawa polifenol, yang mana senyawa ini dapat menghambat bakteri dengan cara merusak membran sitoplasma bakteri yang tersusun oleh $60 \%$ protein dan $40 \%$ lipid yang umumnya berupa fosfolipid. Senyawa katekin merusak membran sitoplasma yang 
menyebabkan bocornya metabolit penting yang menginaktifkan sistem enzim bakteri. Kerusakan pada membran sitoplasma dapat mencegah masuknya bahan-bahan makanan atau nutrisi yang diperlukan bakteri untuk menghasilkan energi akibatnya bakteri akan mengalami hambatan pertumbuhan dan bahkan kematian (Volk and Wheller, 1993).

Setiap sel bakteri dikelilingi membran tipis yang disebut membran sitoplasma atau membran plasma yang tersusun dominan oleh ergesterol yang bersifat permeabel selektif. Selain itu, fosfolipid juga merupakan senyawa yang penting dalam pembentukan membran sitoplasma bakteri. Pada perusakan membran sitoplasma, senyawa katekin melepaskan ion $\mathrm{H}^{+}$yang selanjutnya menyerang gugus hidrofilik (gugus hidroksi dan fosfat) pada permukaan membran sel.

Gugus hidroksi pada molekul ergesterol yang mengadakan ikatan hidrogen tidak mampu mempertahankan ikatan dan kedudukannya. Membran sel tidak mampu menahan tekanan dari dalam, akibatnya sitoplasma dalam sel akan menembus keluar. Selain itu, pada molekul fosfolipid ion $\mathrm{H}^{+}$dari senyawa katekin akan menyerang gugus polar (gugus fosfat) sehingga molekul fosfolipid akan terurai menjadi gliserol, asam karboksilat, dan asam fosfat. Hal ini mengakibatkan fosfolipid tidak mampu mempertahankan bentuk membran sitoplasma akibatnya membran sitoplasma akan bocor sehingga zat-zat untuk metabolisme sel bakteri akan terbuang keluar dan bakteri akan mati. Mekanisme penghambatan pertumbuhan bakteri berupa perusakan fosfolipid pada membran sel bakteri Micrococcus luteus oleh senyawa katekin.

\section{KESIMPULAN}

Senyawa katekindari daun teh (Camelliasinensis, L. varassamica) efektif sebagai antibakteri terhadap bakteri Micrococcusluteus. Senyawa katekin mempunyai aktivitas antibakteri yang paling kuat yaitu isolat 5 dengan memberikan zona hambat 21,3 $\mathrm{mm}$ terhadap bakteri Micrococcusluteus.

\section{DAFTAR PUSTAKA}

Alamsyah, N. A. , 2006, Taklukkan Penyakit dengan Teh Hijau, Penerbit Agrimedia Pustaka, Jakarta.

Al-Jauziyah, I.Q., 2007, Metode Pengobatan Nabi SAW, Penerbit Griya Ilmu, Jakarta.

Amarowicz, R., Maryniak, A., and Shahidi, F., 2005, TLC Separation of Methylated(-)-Epigallocatechin-3-

Gallate, Czech J. Food Sci., Vol. 23, No.1: 36-39.

Anonymous, 2008, Penggunaan Bahan Pengawet,http://www.disnaksumbar.o rgDiakses tanggal 15 Maret 2008.

As-Sayyid, A., B.M, 2006, Pola Makan Rasulullah, Penerbit Almahira, Jakarta.

Buckle, K. A., Edwards, R. A., Fleet, G. H., and Wotton, M., 2007, Ilmu Pangan, Penerbit Universitas Indonesia (UIPRESS), Jakarta.

Gritter, R. J., 1991, Pengantar Kromatografi, edisi kedua, Penerbit ITB, Bandung.

Hadiwiyoto, S., 1993, Teknologi Pengolahan Hasil Perikanan, Liberty: Yogyakarta.

Harborne J.B., 1987, Metode Fitokimia Penuntun Cara Modern Menganalisis Tumbuhan, Penerbit ITB, Bandung.

Hartoyo, A., 2003, Teh dan Khasiatnya Bagi Kesehatan, Penerbit Kanisius, Yogyakarta.

Hukmah, S., Aktivitas Antioksidan Katekin dari Teh Hijau (Camellia Sinensis O.K. Var. Assamica (mast)) Hasil Ekstraksi Dengan Variasi Pelarut dan Suhu, Skripsi Mahasiswa Jurusan Kimia Fakultas Sains dan Teknologi,UIN, Malang.

Imani, A.K.Q, 2005, Tafsir Nurul Quran Sebuah Tafsir Sederhana Menuјu Cahaya Al-Qur'an, Penerjemah Salman Nano, Penerbit Al-Huda, Jakarta. 
Inglis, V., Robert, R., and Bromage, N., 2001, Bacterial Diseases Of Fish, Blackwell Science company, Australia.

Naim, R., 2004, Senyawa Anti mikroba Dari Tanaman, IPB, Bogor. http64.203.71.11kompascetak040915sorotan1265264.htm.htm . Diakses Tanggal 7 April 2008.

Naidu, A.S., 2000, Natural Food Antimicrobial Systems, CRC Press LLC, California State Polytechnic University, Pomana, California.

Nazaruddin farry B. Paimin, 1993, Pembudidayaan dan Pengolahan Teh, Penebar Swadaya, Jakarta.

Noviana, L., 2004, Identifikasi Senyawa Flavonoid Hasil Isolasi dari Proporlis Lebah Madu (Apis Mellifera) dan Uji Aktivitasnya Sebagai Antibakteri (Staphylococcus Aureus), Skripsi Mahasiswa Jurusan Kimia Universitas Brawijaya Malang. Pasya, A.F., 2004, Dimensi Sains dan AlQur'an Menggali Ilmu Pengetahuan dari Al-Qur'an, Penerbit Tiga Serangkai, Solo.

Pelczar, M.J. dan Chan, E.C.S., 1986, Dasar-DasarMikrobiologi, UI Press, Jakarta.

Robert, S.B., E.G.D. Murray, and Nathan R. Smith, 1957, Bergey's Manual of Determinative Bacteriology, Baltimore The Williams and Walkins Company.

Robinson, T., 1995, Kandungan Senyawa Organik Tumbuhan Tinggi, Diterjemahkan oleh Prof. Dr. Kosasih Padmawinata, ITB, Bandung.

Sastrohamidjojo, 2005, Kromatografi, UGM Press, Yogyakarta.

Shihab, Q., 2002, Tafsir Al-Mishbah Pesan, Kesan, dan Keserasian Al-Qur'an Vol. 10, Penerbit Lentera Hati, Jakarta.

Soraya, N, 2007, Sehat Dan Cantik Berkat Teh Hijau, Penebar Swadaya, Jakarta.

Thiagarajan, S., 2006, Micrococcus, Ihttpwww.emlab.comssamplingenvreport-12- 2006.html.mht. Diakses tanggal 18 Juli 2008 